\title{
ARCHAEOLOGY IN GREECE 2016-2017 Stone quarrying in Greece: ten years of research
}

Ben Russell | University of Edinburgh | ben.russell@ed.ac.uk

It has been ten years since the publication of Lorenzo Lazzarini's monumental volume on the quarrying, use and properties of the coloured marbles of Greece: Poikiloi Lithoi, Versiculores Maculae: I Marmi Colorati della Grecia Antica (Lazzarini 2007). The first study since Angelina Dworakowska's Quarries in Ancient Greece (Dworakowska 1975) to attempt a large-scale examination of quarrying across Greece, Lazzarini's approach is fundamentally an archaeometric one. Analysis of the evidence for quarrying in different regions is set alongside minero-petrographic and geochemical analyses of the materials extracted. Lazzarini focuses on 12 lithotypes: marmor lacedaemonium from Laconia, variously referred to as serpentino and porfido verde antico; three stone types from the Mani peninsula: rosso antico tenario, nero antico tenario and cipollino tenario; from Chios, the famous marmor chium or portasanta, breccia di Aleppo and nero antico chiota; the breccia di settebasi and semesanto of Skyros; the intensively exploited marmor carystium or cipollino verde, as well as the marmor chalcidicum or fior di pesco from Euboea; and from central and northern Greece, marmor thessalicum or verde antico and the breccia policroma della Vittoria. For each of these lithotypes, Lazzarini considers the evidence for their use and distribution, illustrated with a distribution map in each case, and provides a thorough overview of what is known about their quarries. Archaeological and geological approaches are here combined, and this is a hallmark of much recent work on the question of quarrying and stone use through Greek history.

Lazzarini's book represents a landmark in the study of decorative stone extraction in Greece. It also followed close on the heels of Silvia Nolte's detailed study of the technical aspects of Greek quarrying and stone carving: Steinbruch - Werkstatt - Skulptur: Untersuchungen zu Aufbau und Organisation griechischer Bildhauerwerkstätten (Nolte 2006). The aim of this article is not to reiterate the conclusions of these two major contributions to the study of stone quarrying in Greece. Rather, it is intended as a brief update on new work in this field since the appearance of these two volumes. Furthermore, this article does not aim at completeness; this is not a catalogue of all work on quarrying in Greece, but rather a list of highlights. Such a catalogue is not necessary, in fact, because one of the most significant highlights of recent work on stone extraction in Greece is the corpus of quarrying sites compiled by Georgia KokkorouAlevras and her team (Kokkorou-Alevras et al. 2014). Since 2001, Kokkorou-Alevras' interdisciplinary team of researchers, comprising archaeologists and geologists, has collected data about more than a thousand quarries in Greece, western Asia Minor and southern Italy, focusing especially on their location, geology and chronology (Kokkorou-Alevras et al. 2009c). While the corpus is effectively a dataset with a limited introduction, the authors have also published a short volume on the operation of ancient quarries, quarrying techniques, transport and economic factors, which is a welcome addition to the Greek scholarship on the subject (Kokkorou-Alevras et al. 2010).

\section{Polychrome stones}

Lazzarini's volume is concerned entirely with polychrome stones, the extraction of which peaked in the Roman Imperial period. This volume effectively summarizes existing research on these materials, provides new archaeometric analyses of them and ultimately stimulated a broad range of new work on large-scale quarrying in Roman Greece. The range of new work in this field is especially evident on Euboea and Skyros.

For Euboea, our understanding of the spread of cipollino quarrying has been substantially increased in the last ten years by survey work in the southeast and centre of the island. Numerous smaller quarries, located between some of the better-known and larger extraction sites, have been identified by the Southern 


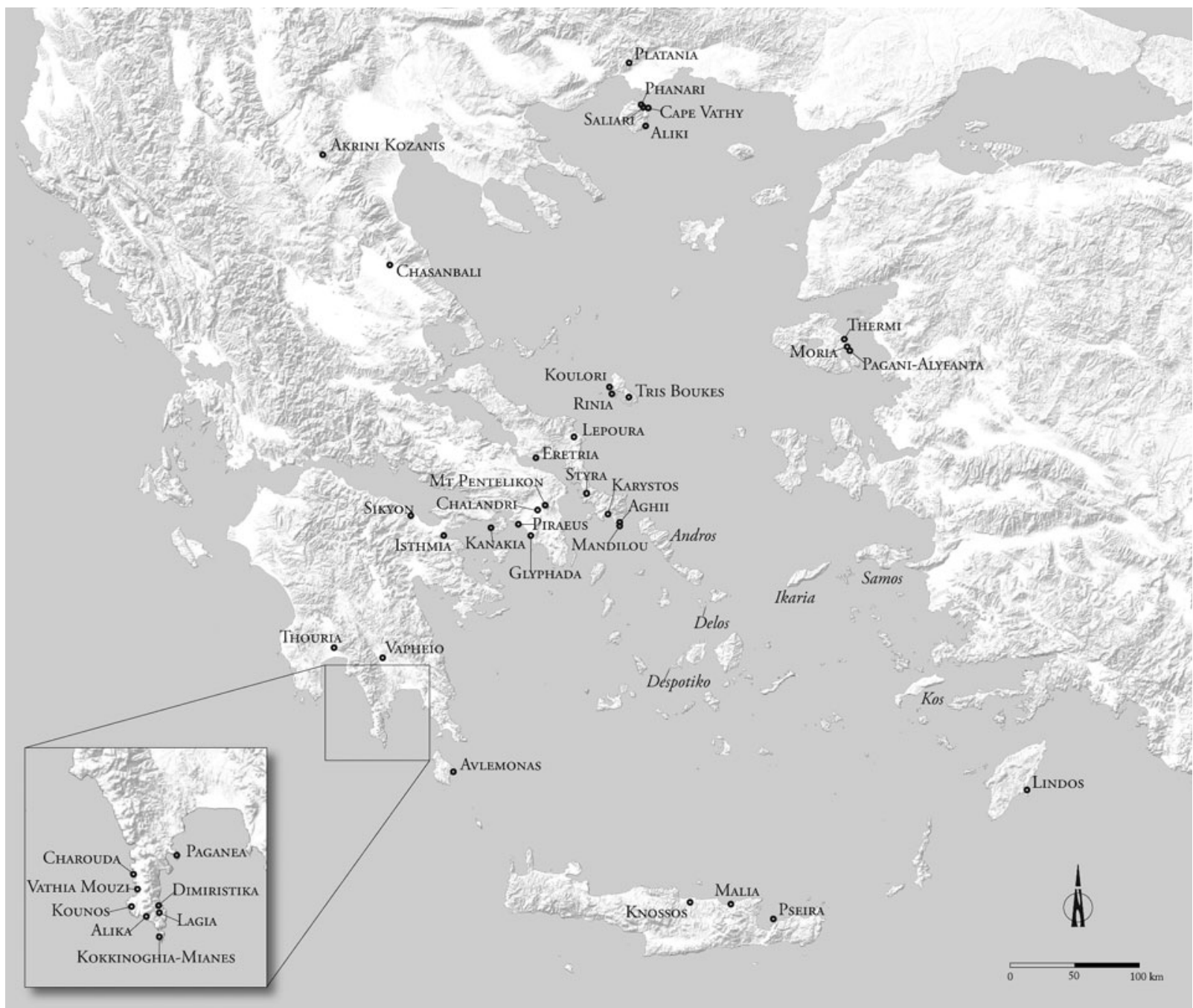

Map 6. Map of key locations/sites mentioned in the text. (C) BSA.

Euboea Exploration Project (Wallace et al. 2006). Many of these sites have now been plotted on the new Tabula Imperii Romani for the Aegean islands (Karvonis et al. 2012). However, the most systematic work in the region has been undertaken by Maria Chidiroglou. Chidiroglou has identified not only a range of previously unknown cipollino quarries on Mount Obores, but has also relocated a quarry with an elaborately carved niche bearing a dedication to Hercules, whose location had been found in the $19^{\text {th }}$ century and then lost (Chidiroglou 2009). Chidiroglou also reports the discovery of two monolithic columns, $6 \mathrm{~m}$ long and inscribed with Latin notae lapicidinarum, on the beach at Nimborio, not far from the quarries at Styra; these appear to have been abandoned during transport (Chidiroglou 2009). Styra used to be considered one of the most northerly cipollino quarries, but in 2012 a series of quarries was published from the fort at Myrtia, 13km north of Styra (Russell and Fachard 2012). The quarrying here post-dates the fort, which is probably Classical, and the extracted stone was exported via the nearby harbour at Panagia, though it was also used locally for sarcophagi. While the discovery of the quarries at Myrtia expands the area of known cipollino quarrying to the north, the identification of series of further cipollino on the coast near Aghii extends it further to the south (Bruno and Vitti 2012). Aghii is $12 \mathrm{~km}$ south of Karystos and the quarries here are on the very southern tip of the island. Aside from quarry-faces themselves, the investigators of these sites identified 26 rectangular blocks, six column shafts and a series of basins, probably used for tempering, an example of which was also found at Myrtia. 
Chidiroglou is also the first to report the existence of a quarry near the village of Lepoura in central Euboea (ID3422; Chidiroglou 2009). This was an area in the territory of Dystos and then, later, Eretria. While Chidiroglou originally identified the stone as white to grey limestone, analysis since has shown that it is actually a pinkish recrystallized limestone that is almost identical to the famous marmor chalcidicum or fior di pesco (Fig. 70; Russell and Fachard 2012). The main source of this highly prized stone, which was intensively exploited and widely traded in the Roman Imperial period, was certainly a quarry just northwest of Eretria. This main quarry has been studied and published by Stephan Schmid, who has identified not just quarry faces but also carved elements, including columns (Schmid 2009). The stone was used locally from the seventh century BC, mainly in construction, but its decorative value was only really appreciated in the Roman period and we begin to see it being exported in the late first century BC (Schmid 2009; Chidiroglou 2016). The discovery of an additional, albeit smaller, fior di pesco quarry at Lepoura, much further south in Eretria's territory, shows that sources of this stone were deliberately sought out in the Roman period. The Lepoura quarries contain multiple monolithic column shafts and, while these are mostly fragmentary, their diameters (ranging from $0.40-0.70 \mathrm{~m}$ ) are in keeping with the diameter of fior di pesco columns in built structures, such as the theatres at Syracuse and Leptis Magna (Fig. 71; Russell and Fachard 2012).

Several surveys in the 2000s on Skyros considerably improved our understanding of the spread of marble extraction on the island and its surrounding islets (Bruno 2002; Lazzarini and Canceliere 2000). In 2011, a further survey of the islets of Rinia and Koulouri, as well as the coast of Skyros opposite Koulouri, identified a series of further quarries, both of the well-known

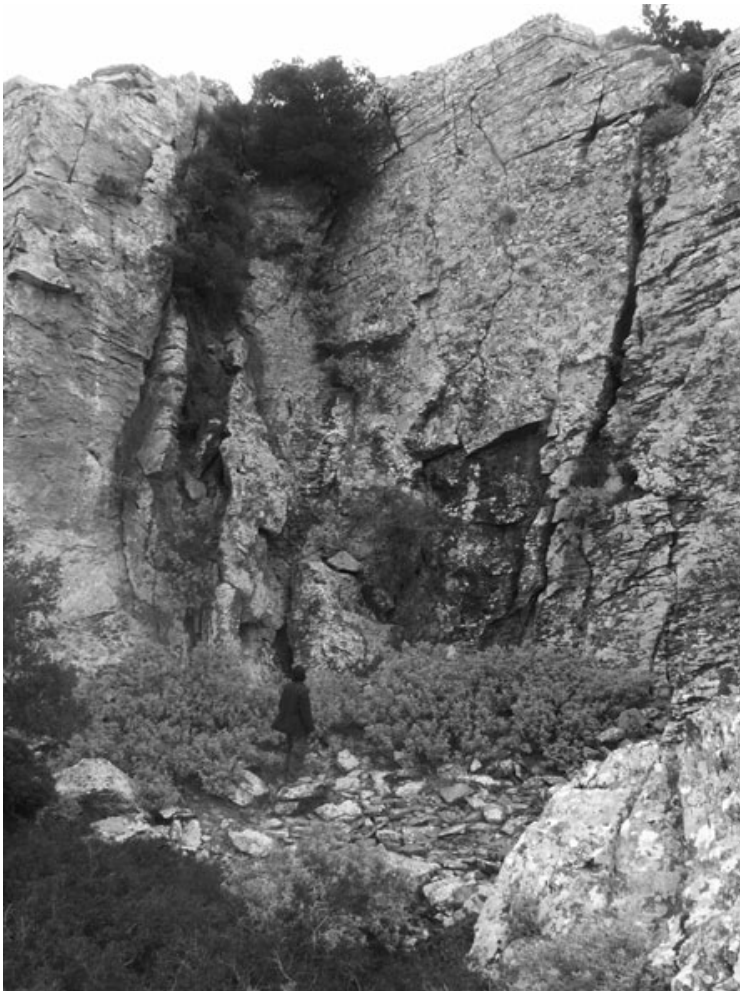

70. Myrtia: the cipollino quarries. (C) B. Russell.

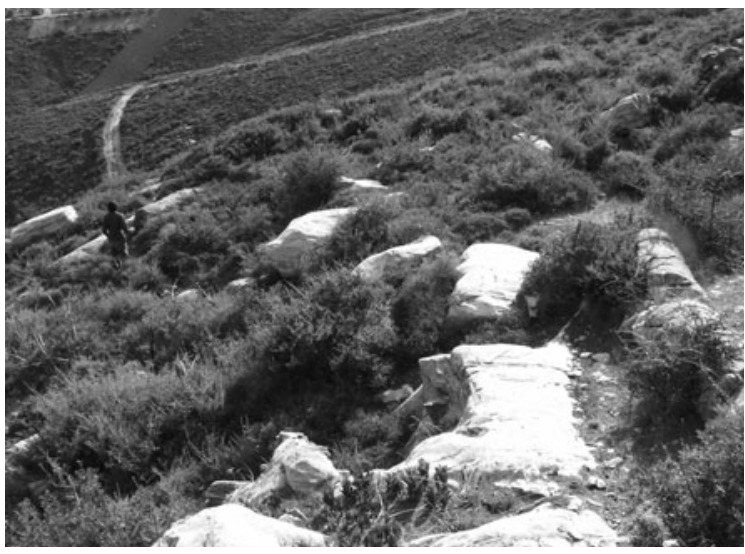

71. Lepoura: the fior di pesco quarries. (C) B. Russell. breccia di settebasi for which the island is famous and of white marble (Karambinis and Lazzarini 2016). At the quarries on Rinia, the investigators note not just quarry-faces but also sockets for posts for lowering blocks down the hillside, of the sort also found at Eretria (Schmid 2009). Some evidence for habitation, in the form of dense surface scatters of pottery - Roman and Late Roman - was also identified on the highest point of the island. This is interpreted, quite reasonably, as evidence for seasonal occupation, since no structures were found. Other post sockets were found at Aliko, on the Oros Cape opposite Koulouri, both in the quarry and along the coast (Karambinis and Lazzarini 2016). Michalis Karambinis also uses this publication to report the discovery at another important marble quarry on Skyros - the breccia di settebasi quarry at Tris Boukes - of a substantial settlement, attested by a dense pottery scatter of material dating from the first to the seventh or eighth century AD (Karambinis and Lazzarini 2016). The same author provides a detailed overview of marble quarrying on Skyros in the monograph of his Leiden doctoral thesis, which for the first time really sets this evidence alongside a general discussion of settlement and land use on the island over the longue durée (Karambinis 2015: 209-12). 
Unlike the quarries on Skyros, those on the Mani peninsula were intensively exploited more recently and, as a result, are only patchily preserved. The most significant of these quarries are at Paganea, Lagia, Kokkinoghia-Mianes and Profitis Elias-Dimiristika. Analysis of the properties of the stone extracted at each of these sites has enabled Lazzarini to distinguish at least between material of the first three quarries, as well between the rosso antico of the Mani and red stones elsewhere, such as that quarried near Iasos (Lazzarini 2007: 71-96). What new work on the Mani has demonstrated is that a range of other stones were also quarried intensively on the peninsula. Maria Tsouli, in particular, has studied the white marble quarries at Charouda and Fourniata, as well as the limestone quarries at Vathia Mouzi, Kounos, Chameleos-Xeropolyana and Alika (Tsouli 2009; Kokkorou-Alevras et al. 2009a). A different aspect of the exploitation of these stone resources has recently been highlighted by Peter Warren, namely the $19^{\text {th }}$ century rediscovery of the rosso antico quarries and the use of this stone in $19^{\text {th }}$ - and $20^{\text {th }}$-century British architecture (Warren 2012). A particularly pertinent example of the use of this stone in Britain is the base of the statue of Byron at Hyde Park Corner in London. The large blocks of rosso antico that constitute this base were supplied in 1880 as a gift from the Greek government.

Two other polychrome stones to have received renewed attention recently are the famous marmor thessalicum or verde antico and the much more obscure breccia policroma della Vittoria. While the quarries of the former of these materials at Chasanbali, north of Larisa in Thessaly, have been known for a long time, the stone itself has only recently been analysed. It is an ophicarbonate metaconglomerate; its fabric is formed by serpentinic and marble elements (Melfos 2008; Lazzarini and Cancelliere 2009). This stone was especially popular in Late Antiquity and was widely used in Constantinople, as well as being reused in major building projects throughout the Middle Ages (Melfos 2008). Breccia policroma della Vittoria, on the other hand, is perhaps the least well known of all the Greek polychrome stones; its ancient name, in fact, is completely unknown. This curious breccia has been found in various Late Antique contexts in northern Greece (including in Thessaloniki and Philippi) but also in Italy, notably at Aquileia and Rome (Lazzarini 2007). It comes in two varieties, one pinkish-grey and the other mottled grey. The Greek source of this stone was confirmed only recently by Lazzarini and Fani Athanasiou, who managed to trace the location of the quarries through modern stonemasons at Thessaloniki who still use the stone (Lazzarini and Athanasiou 2009). The quarries are actually near Akrini in the Kozani province, just south of ancient Beroia and southwest of Pella.

The aesthetic value of grey marble is often downplayed in modern scholarship, but it is quite clear that it was quarried in large quantities from a wide range of regions in Antiquity. Breccia policroma della Vittoria, in fact, often has a greyish tinge and on Lesbos several varieties of grey marble were extracted from the territory of Mytilene. The best known of these quarries is located at Moria, but further areas of extraction have recently been identified at Pagani-Alyfanta (Zachos and Leka 2012). The discovery of this new quarry prompted George Zachos and Evridiki Leka to carry a full survey of quarrying activity on Lesbos and a review of the ancient sources for marmor lesbium (Leka and Zachos 2016). They are able to show that a range of stones was extracted on the island: a white to light-grey marble from Thermi, $10 \mathrm{~km}$ north of Mytilene, the quarries of which have not been found; the distinctive blue-grey marble, a variety of bigio antico, which was quarried at a range of sites (including Moria and Pagani-Alyfanta) in the southeast of the island, in the territory of Mytilene; and, finally, andesite, very similar to the lapis sarcophagus quarried at Assos (Lazzarini and Visonà 2009).

\section{White marble}

The major white marbles of Greece are included in Donato Attanasio's study of the properties of ancient white marbles (Attanasio 2003), while new petrographic and isotopic data for the quarries on Naxos, Paros, Thasos, as well as on Pentelikon and Hymettos are detailed in Lazzarini and Antonelli 2015. Alongside these over-arching studies, several specific advances are worth noting here.

For Pentelic marble, Scott Pike's systematic geochemical and isotopic analyses have substantially added to our understanding of both the geology and exploitation of the marble outcrop over time (Pike 1999; 2009). Pike's detailed survey of Mount Pentelikon has identified at least 172 quarries, of which 30 (and probably many more originally) were certainly worked in Antiquity. These quarries targeted three 
different marble units (1-3), with most ancient activity focused on marble units 2 and 3. Pike's analysis of 610 samples from these quarries shows that it is possible to distinguish isotopically between material from units 2 and 3, and that this has implications for our understanding of where in the quarrying region stone was extracted in different periods. Pike uses these data to demonstrate that the marble sculptures from the Parthenon, now in the British Museum, were quarried from the top of the southern slope and not from the lower and better-preserved Spilia quarry as had previously been suggested (Pike 2009). The utility of Pike's dataset for answering archaeological questions has been further demonstrated in a study of the marble used in the Stoa of Attalos in the Athenian Agora (Bernard and Pike 2016). The results of the analysis of just eight Pentelic blocks from the stoa suggest that marble for the building was extracted from at least two distinct areas of the quarrying district. There is also some similarity between the signature of the one of these groups of material and Pentelic marble used in second-century BC temples of Rome. This raises a number of interesting questions about the supply of Pentelic in the Hellenistic period and the organization and sourcing of material for large-scale construction at Athens. The discovery during rescue excavations in 2009 of a section of the road leading from the Pentelic quarries to Athens adds further detail to our understanding of the supply routes for this material (ID1766). The excavators report that the section of road, excavated in Chalandri, was $3.30 \mathrm{~m}$ wide and preserved wheel ruts on its surface.

For Thasos, the other major source of white marble in Greece, Tony Koželj and Manuela Wurch-Koželj continue to provide detailed data, based on careful first-hand observation, related to quarrying practices on the island. These range from the documentation of inscriptions and dipinti seemingly marking the boundaries of extraction zones in the Cape Phanari quarries (Koželj and Wurch-Koželj 2009), to the study of sawuse in the Roman to Early Byzantine period (Koželj and Wurch-Koželj 2012) and to new observations about sarcophagus production on the island (Wurch-Koželj and Koželj 2009). The latter report, on rectangular sarcophagi from the necropoleis of Thasos itself, builds on their earlier work on the distinctive tubshaped or lenos sarcophagi from the Saliari quarries (Koželj et al. 1985; Wurch-Koželj and Koželj 1995). The broader significance of the evidence for Roman sarcophagus production in the quarries of Thasos can be seen in recent work on the sarcophagus workshops of Thessaloniki. These producers drew heavily on the marble resources of Thasos, as Yannis Maniatis and Dimitris Tambakopoulos show in their analysis published in Theodosia Stefanidou-Tiveriou's study of the local sarcophagi of Thessaloniki (StefanidouTiveriou 2014; for a more concentrated discussion of production aspects, see Stefanidou-Tiveriou 2009). Archaeometric identification of both calcitic and dolomitic Thasian marble even further beyond the shores of the island are also demonstrating that these quarries were among the most significant in the Roman Mediterranean. John Herrmann had already demonstrated that Thasian dolomitic marble, in particular, was widely exported, especially for use in sculptural projects (Herrmann 1999); this hard stone seems to have been used as a raw material by sculptors all around the Mediterranean keen to exploit its decorative and structural properties (Herrmann and Newman 1995). Herrmann has also identified the series of part-worked sarcophagi from the San Pietro in Bevagna shipwreck off southern Puglia as Thasian dolomitic and this has recently been confirmed by isotopic analysis (Giannotta et al. 2016). The same technique has been used to identify the sarcophagi from the nearby wreck at Torre Sgarrata as a combination of dolomitic marble from Cape Vathy and calcitic from Cape Phanari (Calia et al. 2009; Gabellone et al. 2009).

\section{Localized stone extraction}

Most of the quarries noted above have been known about for the best part of a century. New archaeometric and archaeological work is shedding important light on the scale of extraction at these sites, the properties of the materials and their distribution and use, but the quarries themselves are by and large not new discoveries. Away from these major quarrying enterprises, however, new work is increasingly filling in our limited picture of more localized white-marble extraction. This is a trend that is clearly visible elsewhere around the Mediterranean and its neighbouring territories, whereby more carefully focused regional studies have successfully documented hundreds of quarries of local but sometimes interregional significance: cases in point include, the white-marble quarries of the eastern Alps (Djurić and Müller 2009), those of southern Spain and eastern Portugal (Àlvarez et al. 2009; Mañas and Fusco 2008) and those of the Pyrenees (Cabanot et al. 1995). 
In Greece, the small white-marble quarries of the Mani, studied by Tsouli, have already been mentioned (Tsouli 2009). A full overview of quarrying in Laconia more generally is now also available, which for the first time pulls together the evidence for activity of all periods (Kokkorou-Alevras et al. 2009a). On the islands, the small marble quarries on Kos have also received attention (Chatziconstantinou and Poupaki 2009; Lazzarini and Malacrino 2010), as have those on Ikaria and Samos (Varti-Matarangas et al. 2009). These quarries were primarily geared towards local consumption rather than interregional trade; they were relatively small-scale operations, but they were also key components of the local economy and vital resources for nearby urban centres.

Marble, of course, has always attracted the lion's share of scholarly attention. In aggregate terms, however, the quarrying of other stone types was probably always more significant throughout Greek history. The vital importance of limestone, in particular, for large-scale and especially monumental construction has been emphasized recently by Fred Cooper (Cooper 2009). It was this less glamorous material that was the bread and butter of construction activities through Antiquity, a point as true for the Roman period as for earlier periods (Russell 2013). As Cooper noted in 2009, 'a heightened interest in ancient Greek limestone quarries is due and warranted', and there is certainly evidence to suggest this challenge is being met (Cooper 2009: 165).

In Athens, work by Kelly Kouzeli and Eleftheria Dimou has gone some way towards providing context for the high-end use of Pentelic marble in the city (Kouzeli et al. 2004; Kouzeli and Dimou 2009). They draw particular attention to the importance of limestone extracted from the Acropolis and the brown conglomerate ( $\lambda i \theta o \varsigma \alpha \rho o v \rho \alpha i o \varsigma)$ which outcrops at various points in the city for construction throughout Athens' history. These stones were employed alongside a patchwork of other limestones, sandstones and some marble, quarried both in the city and at Piraeus. Rescue excavations at Piraeus, in fact, have identified a large number of small quarries (ID5299, ID5302), as well as several larger ones preserving clear traces of stepped extraction and trenching around blocks (ID4981, ID5295, ID5297). Most of these quarries date to the fifth and fourth centuries $\mathrm{BC}$, though the quarry excavated close to the intersection of Lambraki Street and Distomou Street in 2008 seems to have been used into the Hellenistic period and in this case preserves six courses of block extraction (Fig. 72; ID5295). Further, now submerged, quarries have been found by

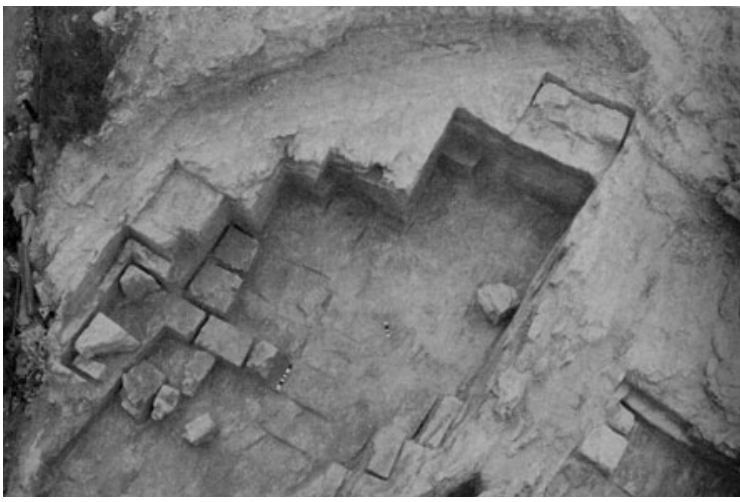

72. Piraeus: Lambraki, Distomou and Androutsou Streets, the quarry. (C) Hellenic Ministry of Culture and Sports: $26^{\text {th }}$ EPCA. the Zea Harbour Project (ID2975).

Even in areas best known for their decorative stones, limestone and sandstone extraction is ubiquitous. On Mani, limestone quarries have been identified at Vathia Mouzi, Kounos, ChameleosXeropolyana and Alika (Tsouli 2009; Kokkorou-Alevras et al. 2009a) On Euboea, Chidiroglou draws attention to limestone and sandstone quarries across much of the island, the stones from which were mainly used for local construction - what she calls 'community markets' (Chidiroglou 2016). These include the limestone and sandstone quarries on the acropolis of Eretria, sandstone quarries on the Paximadhi peninsula near Karystos and on the islet Mandilou, between Euboea and Andros (Chidiroglou 2009; 2016).

A series of small sandstone quarries on Kythera, off southern Laconia, can be added to this list (Kokkorou-Alevras et al. 2009b). One of these quarries, near Avlemonas, contained a small carved room measuring $8 \mathrm{~m}$ by $3 \mathrm{~m}$, one end of which was adorned with a carved niche containing a hermaic stele, possibly of Archaic date. This stele bears a certain a similarity to the herms of Apollo Karneios of seventhand sixth-century BC Laconia, and the room is therefore interpreted as a possible quarry-based sanctuary. A range of toolmarks has been identified in these quarries, including those associated with toothless 
saws. The date of these various quarries cannot be pinpointed with any accuracy. They were certainly in operation by the Archaic period, but their similarity to quarries on Crete might suggest they have Bronze Age phases too.

In the northeastern Peloponnese, Chris Hayward's work in the Corinthia and in the territory of Sikyon has added considerably to our understanding of micro-regional building-stone extraction. At Sikyon, the results of the geoarchaeological survey will appear in the forthcoming publication of the Sikyon Project, however initial discussion of the project's approach and a report on quarrying and stone supply in connection with the building of the theatre have already been published (Lolos et al. 2008; Hayward and Lolos 2015; see also ID289, ID1422). In the Corinthia, Hayward has drawn particular attention to the vast number of quarries of varying size that targeted the region's oolitic, crystalline and impure limestones, as well as conglomerates and sandstones (Hayward 2013). More recently, he has directed the Kenchreai Quarry Survey, which represents perhaps the most systematic survey of a quarrying landscape carried out to date in Greece (for reports from 20132015, see ID4286, ID4887, ID5573). The discovery of a number of inscriptions (the publication of which is forthcoming), which are datable to the Roman period and name quarrymen or contractors, is a particularly valuable result of this work since such documents are comparatively rare outside the major quarries of decorative stone (Fig. 73; on comparanda, see Russell 2013: 56-57). Alongside Hayward's work, large-scale quarrying has also been documented recently at the Sanctuary of Poseidon at Isthmia (ID4882). Rescue archaeology, furthermore, continues to contribute to our understanding of quarrying in the northeastern Peloponnese, with an Archaic quarry discovered during the work to widen the Corinth-Patras road near Corinth (ID2493) and another quarry found in the territory of Sikyon during
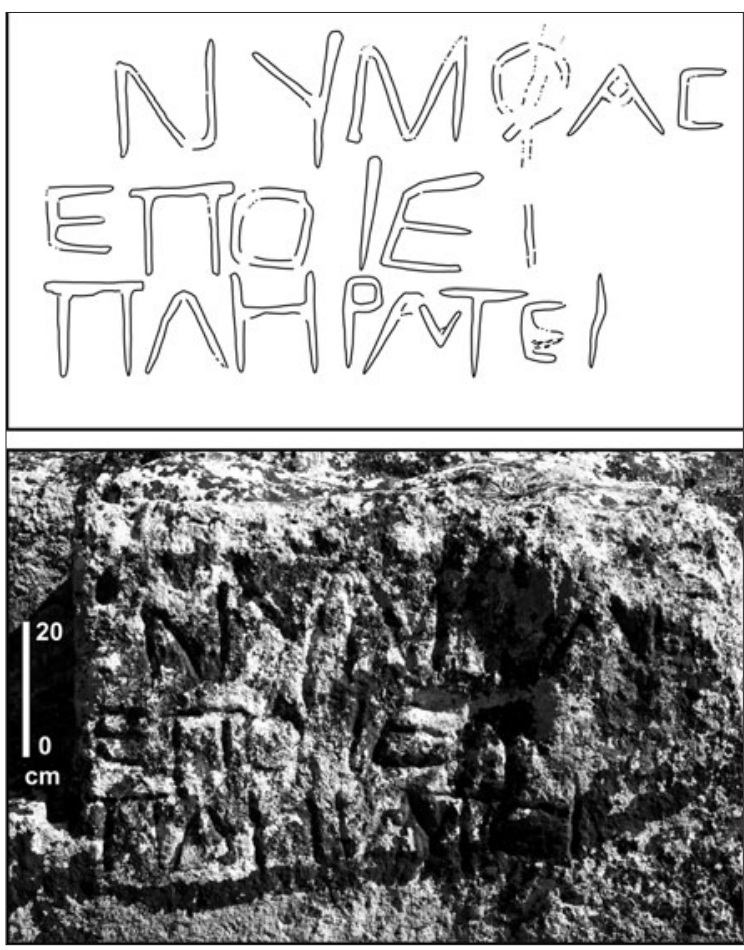

73. Kenchreai quarries: example of an inscription from the 'inscribed quarries' in Complex $B$.

(C) BSA, Kenchreai Quarries Survey. railway work (ID4516).

Our knowledge of small-scale quarrying on Delos has also been substantially enhanced by Panagiotis Hadjidakis, Dionysios Matarangas and Myrsini Varti-Matarangas' survey (Hadjidakis et al. 2009). Many of these quarries targeted granitoid rocks, especially in the central and northern portions of the island, but there was also poros and marble quarrying, some of which has been presented previously in Fraisse and Koželj 1991. These stones were primarily used for basic building on the island; none appear to have merited export and none was of sufficient quality to have been used for high-end carving - for this, imported stones from elsewhere in the Cyclades were used.

Finally, localized quarrying for specific building projects, probably in the immediate vicinity of the quarry, has also been reported from a number of sites, including Thouria in Messenia (ID322), at Glyphada on the outskirts of Athens (ID5268, ID5293), at Lindos on Rhodes (ID5849) and at Platania, north of Kavala (ID4598). Quarrying of building stone for the Archaic sanctuary on Despotiko has also recently been examined (Draganits 2009). This kind of on-site stone extraction is well-documented elsewhere, especially in the Roman period, but tends not to be considered in broader discussions of stone quarrying, which are often interested in the movement of stone after extraction; parallels include the quarries along Hadrian' Wall in Britain (Pearson 2006), those opened for the construction of the Pont du Gard in France (Bessac and Vacca-Goutoulli 2002) and a range of examples in Catalonia (Gutiérrez 2009). 


\section{Pre-Classical quarrying}

While most studies of marble extraction and trade have concentrated on the Classical to the Late Roman period, evidence for marble use in Greece goes back at least as far as the Bronze Age, and perhaps further. The marbles of the Cyclades, in particular, were used for a range of artefacts, including the well-known figurines. While studies of the material of these objects have been attempted (for example Maniatis et al. 2009), without a full and reliable dataset of marble outcrops significant results are elusive. In order to explore the sources of these marbles and whether any evidence for a distribution system could be identified, Tambakopoulos and Maniatis instigated a survey of marble outcrops in the region, analysing samples from them using maximum grain size (MGS), electron paramagnetic spectroscopy (EPR) and stable isotope analysis (IRMS) (Tambakopoulos and Maniatis 2012). As part of this project, the authors sampled marble from Naxos, Keros, Ios, Syros, Nikouria, Schinoussa and Iraklia, creating a database that will be essential for future work on this topic.

Decorative stone use in Minoan contexts has also been examined by Warren, notably the use of red marble (Warren 2011). In fact, Minoan stone quarrying has received an increasing amount of attention over the last decade. Stephania Chlouveraki and Stefano Lugli's work on gypsum quarrying on Minoan Crete highlights the main areas from which this distinctive stone - used decoratively at Knossos and Phaistos, as well as elsewhere - was quarried (Chlouveraki and Lugli 2009). A more detailed study of the properties of the gypsum used at Knossos has been carried out by Kouzeli and Eleni Zgouleta (2009), while further gypsum quarries have been identified by survey in the territory of Knossos (ID2813). The Knossos Urban Landscape Project reports on several large limestone quarries in the hinterland of Knossos that have to date not been fully explored (ID783); one, on Aïlias, seems to be Roman in date.

Additional work on Crete, has fleshed out our understanding of calcarenite quarrying in the territory of Malia (Müller Celka et al. 2011). In this region, the quarries at Potamos and Pyrgos preserve considerable evidence for Minoan quarrying practices, notably in the form of toolmarks, and the surveyors of these sites have been able to produce detailed topographic maps demonstrating the scale of stone extraction. Philip Betancourt and Kostis Davaras have also identified a series of quarries on the island of Pseira, all datable to the Minoan period (ID256, ID760, ID1796, ID1911). These quarries targeted two forms of limestone that were used in the architecture of the settlement alongside mudbrick and locally quarried sandstone. The results of the Galatas Survey, due to be published this year, also promise to shed light on Minoan-era quarrying on Crete; an earlier report refers to Minoan masons' marks on quarried material (ID4537).

Mycenaean quarrying has received less attention to date. On Salamis, however, Yannos Lolos' survey around the Mycenaean residence at Kanakia has identified the quarries from which the grey limestone used in its construction was extracted (ID736). Probably also Mycenaean in date is the conglomerate quarry found in 2006 in the valley between Vapheio and Palaiopyrgi, south of Sparta (ID2561). A useful discussion of Mycenaean stone-carving tools and techniques appears in Nicholas Blackwell's study of the toolmarks on the Lion Gate at Mycenae (Blackwell 2014).

\section{Conclusions}

From a methodological perspective, Sara Franck's use of spectral and GIS analysis for predicting possible quarry locations in the territory of Messene raises a number of interesting questions about the potential of remote sensing for quarry prospection (Franck 2007). Using a Landsat satellite image and ERDAS Imagine software, Franck analysed ground coverage results from known quarries and then used these signatures to identify possible locations of other quarries across the territory. The results of this approach were mixed: on the one hand, three new quarrying areas were identified; on the other, the software identified various areas on the slopes of Mount Ithome where bare limestone was exposed as having similar signatures to the known quarries, as one might expect. It is possible that this approach, however, might provide greater insight into less rugged terrains, in northwestern Europe for instance, where LiDAR scanning is already showing great potential (for quarrying on Hadrian's Wall, see Collins 2015). Laser scanning and photogrammetry have been employed elsewhere for the documentation of quarries and could usefully be applied to the study of Greek quarries. 
In sum, the increasing interest in localized marble quarrying and especially the ubiquitous quarrying of limestone, sandstone and other less-glamorous materials throughout Greece has helped to flesh out substantially our understanding of stone use across periods. Intensive survey of whole quarrying landscapes, as undertaken in the Corinthia and on Euboea, and the exploration of the management of these natural resources has the potential to illuminate a range of questions relating to building activity and the functioning of the Greek economy. Research on the major decorative stone quarries of the country continues to add important new information about the white marbles of Pentelikon and Thasos, two of the most widely used decorative stones around the Roman Mediterranean. The recent discovery of the breccia policroma della Vittoria quarries shows that there remain gaps in our knowledge about some of even the most widely distributed polychrome stones.

\section{Bibliography}

Àlvarez, A., Domènech, A., Lapuente, M.P., Pitarch, À. and Royo, H. (2009) Marbles and Stones of Hispania: Exhibition Catalogue (Tarragona)

Attanasio, D. (2003) Ancient White Marbles: Analysis and Identification by Paramagnetic Resonance Spectroscopy (Rome)

Bernard, S.G. and Pike, S. (2016) 'Isotopic analysis of marble from the Stoa of Attalos in the Athenian Agora and the Hellenistic quarries of Mount Pentelikon', in P. Pensabane and E. Gasparini (eds), Interdisciplinary Studies on Ancient Stones (Rome) 451-59

Bessac, J.-C. and Vacca-Goutoulli, M. (2002) 'La carrière romaine de L'Estel près du Pont du Gard', Gallia 59, 11-28

Blackwell, N. (2014) 'Making the Lion Gate relief at Mycenae: tool marks and foreign influence', AJA $118.3,451-88$

Bruno, M. (2002) 'The quarries at Cape Latomio on Valaxa island, Skyros (Greece)', in J.J. Herrmann Jr, N. Herz and R. Newman (eds), Interdisciplinary Studies on Ancient Stone (London) 27-35

Bruno, M. and Vitti, M. (2012) 'Cipollino marble quarries south of Karystos at Aghii (Euboea, Greece)', in A. Gutiérrez, P. Lapuente and I. Rodà (eds), Interdisciplinary Studies on Ancient Stone: Proceedings of the IX ASMOSIA Conference (Tarragona 2009) (Tarragona) 604-11

Cabanot, J., Sablayrolles, R. and Schenk, J.-L. (eds) (1995) Les marbres blancs des Pyrénées: approaches scientifiques et historiques (Toulouse)

Calia, A., Giannotta, M.T., Lazzarini, L. and Quarta, G. (2009) 'The Torre Sgarrata wreck: characterization and provenance of white marble artefacts in the cargo', in Y. Maniatis (ed.), ASMOSIA VII (Athens) $333-42$

Chatziconstantinou, A. and Poupaki, E. (2009) 'The question of marble quarrying on Kos island during Antiquity', in Ç. Özkan Aygün (ed.), SOMA 2007: Proceedings of the XI Symposium on Mediterranean Archaeology (Oxford) 61-67

Chidiroglou, M. (2009) 'New data on the ancient quarries in southern Euboea, Greece', in P. Jockey (ed.), Leukos lithos. Marbres et autres roches de la Méditerranée antique: études interdisciplinaries (Paris) 73-91

- (2016) 'Small Euboean quarries: the local community markets', in P. Pensabane and E. Gasparini (eds), Interdisciplinary Studies on Ancient Stones (Rome) 63-72

Chlouveraki, S. and Lugli, S. (2009) 'Gypsum: a jewel in Minoan palatial architecture; identification and characterization of its varieties', in Y. Maniatis (ed.), ASMOSIA VII (Athens) 657-68

Collins, R. (2015) Hadrian's Wall and LiDAR: New Features in an Ancient Frontier Landscape (Newcastle) https://research.ncl.ac.uk/fredhi/research/HadsWall\%20LiDAR\%20report.pdf

Cooper, F.A. (2009) 'Limestone quarries for Greek cities and sanctuaries', in P. Jockey (ed.), Leukos lithos. Marbres et autres roches de la Méditerranée antique: études interdisciplinaries (Paris) 161-76

Djurić, B. and Müller, H.W. (2009) 'White marbles in Noricum and Pannonia: an outline of the Roman quarries and their products', in P. Jockey (ed.), Leukos lithos. Marbres et autres roches de la Méditerranée antique: études interdisciplinaries (Paris) 111-27 
Draganits, E. (2009) 'The Archaic sanctuary on Despotiko island (Cyclades): geological outline and lithological characterization of the building stones with their possible provenance', Austrian Journal of Earth Sciences 102, 91-101

Dworakowska, A. (1975) Quarries in Ancient Greece (Warsaw)

Fraisse, P. and Koželj, T. (1991) 'Une carrière de marbre au Sud-Est du Cynthe', Bulletin de correspondance hellénique 115, 283-96

Franck, S. (2007) 'Spectral and GIS analysis for quarry location in ancient Messene, Greece', in A. Posluschny, K. Lambers and I. Herzog (eds), Layers of Perceptions: Proceedings of the $35^{\text {th }}$ International Conference on Computer Applications and Quantitative Methods in Archaeology (Bonn) 164 70

Gabellone, F., Giannotta, M.T. and Alessio, A. (2009) 'The Torre Sgarrata wreck (south Italy): marble artefacts in the cargo', in Y. Maniatis (ed.), ASMOSIA VII (Athens) 319-31

Giannotta, M.T., Quarta, G., Alessio, A. and Pennetta, A. (2016) 'Provenance of the Roman marble sarcophagi of the San Pietro in Bevagna wreck', in P. Pensabane and E. Gasparini (eds), Interdisciplinary Studies on Ancient Stones (Rome) 143-53

Gutiérrez, A. (2009) Roman Quarries in the Northeast of Hispania (Tarragona)

Hadjidakis, P., Matarangas, D. and Varti-Matarangas, M. (2009) 'Ancient quarries in Delos, Greece', in Y. Maniatis (ed.), ASMOSIA VII (Athens) 273-88

Hayward, C.L. (2013) 'Corinthian stone exploitation and the interpretation of inscribed building accounts', in K. Kissas and W.-D. Niemeier (eds), The Corinthia and Northwest Peloponnese (Athens) 63-78

Hayward, C.L. and. Lolos, Y (2015) 'Building the Early Hellenistic theatre at Sikyon', in R. Frederiksen, E. Gebhard and A. Sokolicek (eds), The Architecture of the Ancient Greek Theatre (Aarhus) 161-72

Herrmann, J. (1999) 'The exportation of dolomitic marble from Thasos: a short overview', in C. KoukouleChrusanthake, A. Muller and S. Papadopoulos (eds), Thasos: matière premières et technologie de la préhistoire à nos jours (Paris) 57-74

Herrmann, J. and Newman, R. (1995) 'The exportation of dolomitic marble from Thasos: evidence from Mediterranean and other collections', in Y. Maniatis, N. Herz and Y. Basiakos (eds), The Study of Marble and Other Stones Used in Antiquity. ASMOSIA III (London) 73-86

Karambinis, M. (2015) The Island of Skyros from Late Roman to Early Modern Times: An Archaeological Survey (Leiden)

Karambinis, M. and Lazzarini L. (2016) 'The Roman marble quarries of Aliko Bay and of the islets of Rinia and Koulouri (Skyros, Greece)', in P. Pensabane and E. Gasparini (eds), Interdisciplinary Studies on Ancient Stones (Rome) 791-804

Karvonis, P., Mikedaki, M. and Zachos, G. (2012) Tabula Imperii Romani, J35 - Smyrna I: Aegean Islands (Athens)

Kokkorou-Alevras, G., Chatzikonstantinou, A., Efstathopoulos, A., Zavvou, E., Themos, N., Kopanias, K. and Poupaki, E. (2009a) 'Ancient quarries in Laconia', in W.G. Cavanagh, C. Gallou and M. Georgiadis (eds), Sparta and Laconia: From Prehistory to the Pre-Modern (London) 169-79

Kokkorou-Alevras, G., Efstathopoulos, A., Poupaki, E. and Chatziconstantinou, A. (2009b) 'Ancient quarries of Kythera', in P. Jockey (ed.), Leukos lithos. Marbres et autres roches de la Méditerranée antique: études interdisciplinaries (Paris) 177-88

Kokkorou-Alevras, G., Poupaki, E., Chatzikonstantinou, A. and Efstathopoulos, A. (2009c) 'Corpus of ancient Greek quarries', in Y. Maniatis (ed.), ASMOSIA VII (Athens) 709-18

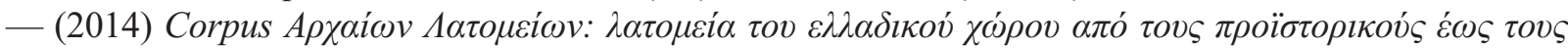

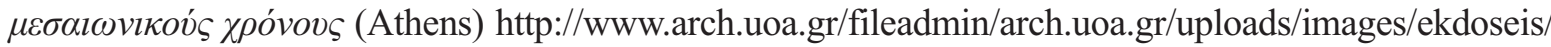
corpus_of_ancient_quarries.pdf

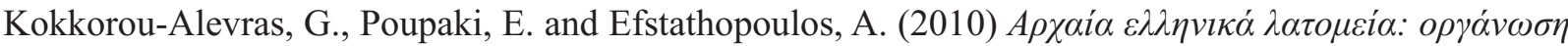

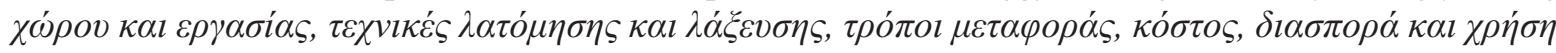
$\lambda i \theta \omega v$ (Athens)

Kouzeli, K. and Dimou, E. (2009) 'Building material (except Pentelic marble) used in ancient Athens', in 
P. Jockey (ed.), Leukos lithos. Marbres et autres roches de la Méditerranée antique: études interdisciplinaries (Paris) 291-308

Kouzeli, K., Lazari, C. and Dimou, E. (2004) 'Fossiliferous limestones used in ancient Greek monuments: the influence of their specific features on their durability', in D. Kwiatkowski and R. Löfvendahl (eds), Tenth International Congress on Deterioration and Conservation of Stone (Stockholm) 123-30

Kouzeli, K. and Zgouleta, E. (2009) 'Gypsum at the Minoan site of Knossos: types and deterioration', in Y. Maniatis (ed.), ASMOSIA VII (Athens) 764-76

Koželj, T., Lambraki, A., Muller, A. and Sodini, J.O. (1985) 'Sarcophages découverts dans les carriers de Saliari (Thasos)', in P. Pensabene (ed.), Marmi antichi: problem d'impiego, di restauro e d'identificazione (Rome) 75-82

Koželj, T. and Wurch-Koželj, M. (2009) 'Les carriers du Cap Phanari à Thasos', in P. Jockey (ed.), Leukos lithos. Marbres et autres roches de la Méditerranée antique: études interdisciplinaries (Paris) 49-71

- (2012) 'Use of a saw in Roman and proto-Byzantine period on the island of Thasos', in A. Gutiérrez, P. Lapuente and I. Rodà (eds), Interdisciplinary Studies on Ancient Stone: Proceedings of the IX ASMOSIA Conference (Tarragona 2009) (Tarragona) 715-22

Lazzarini, L. (2007) Poikiloi Lithoi, Versiculores Maculae: I Marmi Colorati della Grecia Antica. Storia, Uso, Diffusione, Cave, Geologia, Caratterizzazione Scientifica, Archeometria, Deterioramento (Pisa)

Lazzarini, L. and Antonelli, F. (2015) 'An updated petrographic and isotopic reference database for white marbles used in Antiquity', Rendiconti Lincei (Scienze fisiche e naturali) 26.4, 399-413

Lazzarini, L. and Athanasiou, F. (2009) 'The discovery of the Greek origin of the Breccia Policroma della Vittoria', in Y. Maniatis (ed.), ASMOSIA VII (Athens) 669-76

Lazzarini, L. and Canceliere, S. (2000) 'Characterisation of the white marble of two unpublished ancient Roman quarries on the islands of Fourni and Skyros (Greece)', Periodico di Mineralogia 69, 49-62

- (2009) 'Marmor Thessalicum (verde antico): source, distribution and characterization', in Y. Maniatis (ed.), ASMOSIA VII (Athens) 495-508

Lazzarini, L. and Malacrino, C.G. (2010) 'The white marble of Kos, its quarries and archaeometric characterisation', Marmora 6, 57-70

Lazzarini, L. and Visonà, D. (2009) 'Lapis sarcophagus and the provenance of its Mediterranean sarcophagi', in P. Jockey (ed.), Leukos lithos. Marbres et autres roches de la Méditerranée antique: études interdisciplinaries (Paris) 369-88

Leka, E. and Zachos, G. (2016) 'The marmor lesbium reconsidered and other stones of Lesbos', in P. Pensabane and E. Gasparini (eds), Interdisciplinary Studies on Ancient Stones (Rome) 201-11

Lolos, Y., Gourley, B., Sarris, A., Hayward, C., Trainor, C., Kiriantzi, E. and Papadopoulos, N. (2008) 'Surveying the Sikyonian plateau: an integrated approach to the study of an ancient cityscape', in N. Zacharias, M. Georgakopoulou, K. Polikreti, Y. Facorellis and T. Vakoulis (eds), Proceedings of the $5^{\text {th }}$ Symposium of the Hellenic Society of Archaeometry (Athens) 305-26

Mañas, I. and Fusco, A. (2008) 'Canteras de Lusitania: un anális arqueológico', in T. Nogales and J. Beltrán (eds), Marmora Hispania: explotación y uso de los materiales pétreos en la Hispania romana (Rome) 481-522

Maniatis, Y., Sotirakopoulou, P., Polikreti, K., Dotsika, E. and Tzavidopoulos, I. (2009) 'The "Keros Hoard": provenance of marbles and their possible sources with a combination of scientific techniques', in Y. Maniatis (ed.), ASMOSIA VII (Athens) 413-37

Melfos, V. (2008) 'Green Thessalian stone: the Byzantine quarries and the use of a unique architectural material from the Larisa area, Greece. Petrographic and geochemical characterization', Oxford Journal of Archaeology 27.4, 387-405

Müller Celka, S., Laffineur, R., Anslijn, J.-N. and Gomrée, T. (2011) 'Recherches dans les carriers de

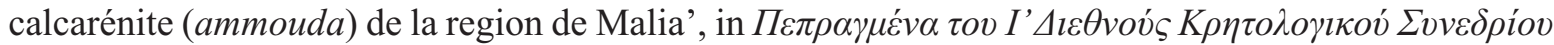

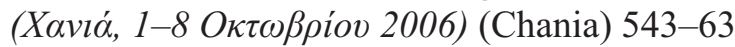

Nolte, S. (2006) Steinbruch - Werkstatt - Skulptur: Untersuchungen zu Aufbau und Organisation griechischer Bildhauerwerkstätten (Göttingen) 
Pearson, A. (2006) The Work of Giants: Stone and Quarrying in Roman Britain (Stroud)

Pike, S. (1999) 'Preliminary results of a systematic characterization study of Mount Pentelikon, Attica, Greece', in M. Schvoerer (ed.), Archéomatériaux: marbes et autres roches (Bordeaux) 165-70

- (2009) 'A stable isotope database for the ancient white marble quarries of Mount Pentelikon, Greece', in Y. Maniatis (ed.), ASMOSIA VII (Athens) 699-708

Russell, B. (2013) The Economics of the Roman Stone Trade (Oxford)

Russell, B. and Fachard, S. (2012) 'New work on quarrying in the territory of Eretria, Euboea', in A. Gutiérrez, P. Lapuente and I. Rodà (eds), Interdisciplinary Studies on Ancient Stone: Proceedings of the IX ASMOSIA Conference (Tarragona 2009) (Tarragona) 612-18

Schmid, S.G. (2009) 'Marmor chalcidicum vel eretrianum: réflexions sur l'économie et le commerce d'Érétrie à l'époque impériale', in P. Jockey (ed.), Leukos lithos. Marbres et autres roches de la Méditerranée antique: études interdisciplinaries (Paris) 527-42

Stefanidou-Tiveriou, T. (2009) 'Thasian marble: a connection between Thasos and Thessaloniki', in Y. Maniatis (ed.), ASMOSIA VII (Athens) 19-29

- (2014) Die lokalen Sarkophage aus Thessaloniki (Ruhpolding)

Tambakopoulos, D. and Maniatis, Y. (2012) 'The search for the Prehistoric marble sources in the Cyclades', in A. Gutiérrez, P. Lapuente and I. Rodà (eds), Interdisciplinary Studies on Ancient Stone: Proceedings of the IX ASMOSIA Conference (Tarragona 2009) (Tarragona) 287-99

Tsouli, M. (2009) 'Contribution to the study of the ancient marble quarries of the Mani peninsula, SW Laconia, Peloponnese: the case of the white-grey marble quarry at the site of Charouda, near Pyrgos Dirou, and of the cipollino verde antico quarry at the site of Paliros-Koureloi, near Cape Tainaron', in Ç. Özkan Aygün (ed.), SOMA 2007: Proceedings of the XI Symposium on Mediterranean Archaeology (Oxford) 396-403

Varti-Matarangas, M., Matarangas, D. and Lazzarini, L. (2009) 'The marbles of Ikaria and Samos (Greece): quarries and characterization', in P. Jockey (ed.), Leukos lithos. Marbres et autres roches de la Méditerranée antique: études interdisciplinaries (Paris) 31-48

Wallace, M., Keller, D., Wickens, J. and Lamberton, R. (2006) 'The Southern Euboea Exploration Project: 25 years of archaeological research', in M. Chidiroglou and A. Chatzidimitriou (eds), Antiquities of Karystia (Karystos) 18-51

Warren, P. (2011) “"Red” marble in the Aegean Bronze Age', in F. Carinci, N. Cucuzza, P. Militello and

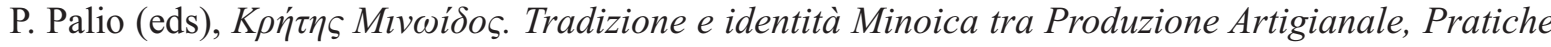
Cerimoniali e Memoria del Passato (Padua) 190-206

- (2012) 'The rediscovery of Greek rosso antico marble and its use in Britain in the nineteenth and twentieth centuries', BSA 107, 341-86

Wurch-Koželj, M. and Koželj, T. (1995) 'Roman quarries of apse-sarcophagi in Thasos of the second and third centuries', in Y. Maniatis, N. Herz and Y. Basiakos (eds), The Study of Marble and Other Stones Used in Antiquity (London) 39-50

- (2009) 'Quelques sarcophages rectangulaires d'époque impériale, des carrière thasiennes aux nécropoles de Thasos', in Y. Maniatis (ed.), ASMOSIA VII (Athens) 289-307

Zachos, G.A. and Leka, E. (2012) 'The ancient quarry at Pagani-Alyfanta, Lesbos, Greece', in A. Gutiérrez, P. Lapuente and I. Rodà (eds), Interdisciplinary Studies on Ancient Stone: Proceedings of the IX ASMOSIA Conference (Tarragona 2009) (Tarragona) 592-603 